\title{
Preliminary data on the millipedes (Diplopoda) from the Stavropol Territory, northern Caucasus, Russia
}

\author{
Предварительные данные по двупарноногим многоножккам \\ (Diplopoda) Ставропольского края (Северный Кавказ, Россия)
}

\author{
R.V. Zuev \\ P.B. Зуев \\ Северокавказский федеральный университет, ул. Пушкина 1, г. Ставрополь, 355009, Россия. \\ North Caucasian Federal University, Pushkina Str. 1, Stavropol 355009 Russia. \\ KEY WORDS: Diplopoda, faunistics, Stavropol Territory, Ciscaucasia. \\ КЛЮЧЕВЫЕ СЛОВА: Diplopoda, фаунистика, Ставропольский край, Предкавказье.
}

ABSTRACT. The millipede fauna of the Stavropol Territory, northern Caucasus comprises at least 19 species; 12 of them are new to the regional list, including two new to the fauna of Russia: Brachydesmus assimilis Lohmander, 1936 and Cylindroiulus arborum Verhoeff, 1928. Faunistic records of all these species in the Territory are presented and mapped.

РЕЗЮМЕ. Фауна двупарноногих многоножек Ставропольского края включает, по крайней мере, 19 видов, из них 12 впервые приведены для исследуемой территории, в т.ч. 2 - новые для фауны России: Brachydesmus assimilis Lohmander, 1936 и Cylindroiulus arborum Verhoeff, 1928. Представлены фаунистические находки и карты с указанием распространения этих видов в регионе.

\section{Introduction}

Ciscaucasia, i.e. the territories lying immediately north of the Caucasus Major mountains, is since the $19^{\text {th }}$ century subjected to various, but mostly considerable levels of anthropogenic pressure. The Stavropol Territory, northern Caucasus, Russia is no exception to this, as presently more than $80 \%$ of its territory are being used for agri- or horticultural purposes. These changes clearly concern the mostly steppe ecosystems the region supports, including the largely mesophilous class Diplopoda as one of the major components of soil fauna.

The millipedes of the Stavropol Territory remain still quite poorly studied. The available information mostly concerns the Caucasian Mineral Waters area. Thus, Megaphyllum rossicum (Timotheew, 1897) was partly based on material coming from Kislovodsk [Timotheew, 1897]. Muralewicz [1907, 1927] recorded several European species from near Kislovodsk and Pyatigorsk, based on clearly misidentified samples. Hardly surprisingly, they have since been fully neglected [e.g. Lohmander, 1936; Read, 1992]. Lohmander
[1936] reported Rossiulus kessleri (Lohmander, 1927) (referred to as Sarmatiulus kessleri) from Pyatigorsk, while Golovatch \& Enghoff [1990], Golovatch \& Matyukhin [2011] and Evsyukov \& Golovatch [2013] recorded seven species of Diplopoda in the Caucasian Mineral Waters area: Strongylosoma kordylamythrum (Attems, 1898), Nopoiulus kochii (Gervais, 1847), Nemasoma caucasicum (Lohmander, 1932), Unciger transsilvanicus (Verhoeff, 1899) Megaphyllum brachyurum (Attems, 1899), Megaphyllum rossicum and Rossiulus kessleri.

\section{Material and methods}

The material underlying this paper was collected in 2004-2014 in different places and habitats of the Stavropol Territory. Specimens were taken either by hand or using soil sampling. All material is deposited in the Zoological Museum of the North Caucasian Federal University, Stavropol, Russia.

\section{Taxonomic part \\ ORDER GLOMERIDA \\ Family DODERIIDAE \\ Trachysphaera costata (Waga, 1857) Map 1.}

MATERIAL. 31 ㅇ, 4 juv., Stavropol Territory, Stavropol City, Tamansky Forest, 14.IV.2013; 2 우, same locality, 15.VI.2013; 4 운, same locality, 12.IX.2013; 7 우, same locality, 8.X.2013; 1 , Predgornyi Distr., Pyatigorsk, Mashuk Mountain, forest, 20. VII.2013; 1 +, 3 juv., Shpakovsky Distr., 5 km SSE of Izveshchatelnyi, Strizhament Mountain, forest, 14.VII.2013; 10 우, same locality, 9.VII.2014; 6 우, Kochubeevsky Distr., Nevinnomyssk, confluence of Bolshoy Zelenchuk and Kuban rivers, floodplain forest, in rotting wood, 7.IX.2014, all leg. R.V. Zuev.

REMARKS. This species is quite common in Eastern Europe, the Balkans, the Carpathians, the Crimea, the Caucasus, Turkey and northwestern Iran [Golo- 


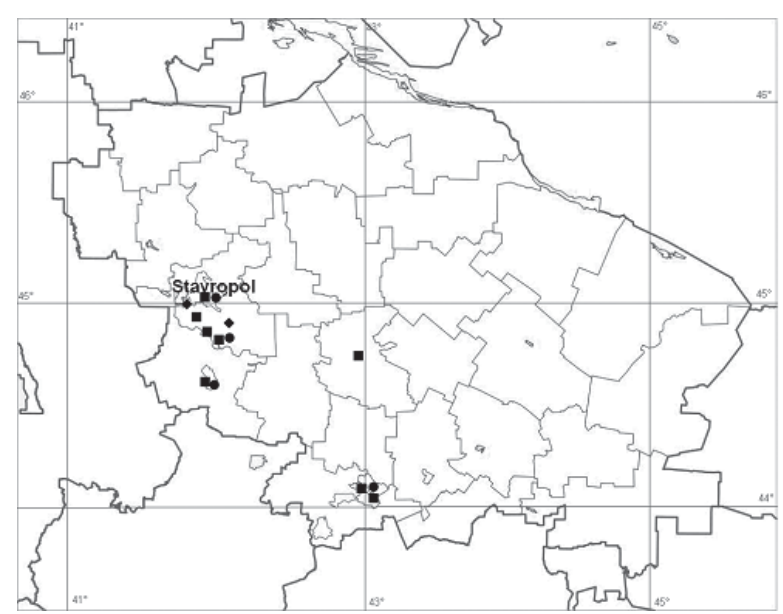

Map 1. Distribution of millipedes in the Stavropol Territory: circle - Trachysphaera costata; square - Strongylosoma kordylamythrum; diamond — Polydesmus muralewiczi.

Карта 1. Распространение двупарноногих многоножек в Ставропольском крае: круг — Trachysphaera costata; квадрат Strongylosoma kordylamythrum; ромб — Polydesmus muralewiczi.

vatch, 1989, 2008], usually dwelling in forest habitats, sometimes also in caves, often on limestone bedrock [Chornyi, Golovatch, 1993]. It can be found in the soil, sometimes under the bark and in rotting wood. In the Stavropol Territory, this species seems to be fully represented by parthenogenetic populations, although bisexual populations are known from the neighbouring Krasnodar Territory and Chechen Republic [Golovatch, 1989, 2008].

\section{ORDER POLYDESMIDA Family PARADOXOMATIDAE}

\section{Strongylosoma kordylamythrum Attems, 1898 Map 1.}

MATERIAL. $3 \sigma^{\top} \sigma^{\top}, 3$, 9 , Stavropol Territory, Stavropol City, Tamansky Forest, 7.IV.2011; $1 \sigma^{7}$, same locality, 14.V.2011; 2 OO 1 juv., same locality, 7.VII.2011; 1 +, same locality, 14.IV.2012; 1 $\sigma^{\top}, 2$ juv., same locality, 8.IX.2012; $2 \sigma^{\top} \sigma^{\top}, 3$ 우, same locality, 10 IX.2013; $3 \sigma^{\top} \sigma^{\top}, 3$ OQ, 1 juv., same locality, 12.IX.2013; $1 \sigma^{\top}, 5$ 우, same locality, 5.X.2013; $1 \sigma^{\top}, 4$ 우, same locality, 9.X.2013; 1 ๙", Mamaysky Forest, 2.VIII.2012; $6 \bigcirc^{\top} \sigma^{7}, 1$, same locality, 29.VI.2013; 3 juv., same locality, 3.VIII.2013; 1 ㅇ, Russky Forest, 6.IV.2013; 1 juv., same locality, 27.VII.2013; $2 \sigma^{7} \sigma^{7}$, same locality, 7.VI.2014; 3 ๙ $^{7}, 1$ \% , Botanical Garden, 10.IV.2014; 1 , Shpakovsky Distr., 5 km SSE of Izveshchatelnyi, Strizhament Mountain, forest, 3.VI.2010; 2 क+ , same locality, 14.VII.2013; $3 \sigma^{\top} \sigma^{\top}, 1$ + 1 juv., same locality, 9.VII.2014; $2 \sigma^{7} \sigma^{\top}, 1$ ㅇ, Verhneegorlyksky, Lopatin Forest, 9.VI.2012; $3 \sigma^{\top} \sigma^{\top}, 4$ 우, Nedremannaya Mountain, forest, 19.IV.2013; $2 \sigma^{\top} \sigma^{7}, 1$, 1 juv., same locality, 15.VII.2014; 1 ㅇ, Alexanderovsky Distr., Alexandrovskoe, forest, 8.VI.2011; 1 juv., Kochubeevsky Distr., Nevinnomyssk, confluence of Bolshoy Zelenchuk and Kuban rivers, floodplain forest, 7.IX.2014; $2 \sigma^{7} \sigma^{7}$ 1 9, 4 juv. Predgornyi Distr., Pyatigorsk, Mashuk Mountain, forest, 20.VII.2013; 1 juv., Beshtau Mountain, forest, 21.VII.2013, all leg. R.V. Zuev.

REMARKS. This species is widespread almost throughout the Caucasus, also known from northern and northwestern Iran [Evsyukov et al., 2015]. The northern range limit of this species crosses the Rostov-
on-Don Region, Russia [Evsyukov, Golovatch, 2013]. In the Stavropol Territory, it has been reported from the Caucasian Mineral Waters area [Lohmander, 1936; Golovatch, Matyukhin, 2011; Evsyukov et al., 2015], at Kislovodsk found also in bird nests [Golovatch, Matyukhin, 2011]. According to our data, S. kordylamythrum is likewise common in forests over the plain parts of the region where it is a usual species.

\section{Oxidus gracilis (C.L. Koch, 1847)}

MATERIAL: 19 , Stavropol Territory, Stavropol City, Botanical Garden, under stone on open grounds, 16.VI.2012, leg. R.V. Zuev.

REMARKS. This anthropochore subcosmopolitan species of East Asian origin is usual indoors in greenand hothouses throughout the world, but along the Black Sea coast of the Caucasus it is also known from natural habitats [Lignau, 1907; Lohmander, 1936]. The only sample referred to above was found on open grounds near a greenhouse.

\section{Family POLYDESMIDAE}

Polydesmus muralewiczi Lohmander, 1936 Fig. 1, Map 1.

MATERIAL. $1 \sigma^{7}$, Stavropol Territory, Shpakovsky Distr., near Tsimlyansky, steppe, 16.V.2011; $1 \sigma^{7}$, same locality, forested steppe, 20.V.2013; 1 $\sigma^{7}$, near Grushevyi, steppe, under stone, 28.X.2013; 1 o', 3 우, 1 juv., same locality, 23.III.2014, all leg. R.V. Zuev.

REMARKS. These seem to be the northernmost records of this species. Originally described from Psebai, Krasnodar Territory [Lohmander, 1936], it is also known from western Georgia at altitudes of up to 2300 $\mathrm{m}$ [Kobakhidze, 1965]. We found it in steppe habitats under stones and logs. Its habitus, especially the relatively narrow paraterga as compared to the remaining few Caucasian congeners, is quite characteristic (Fig. 1).

\section{Brachydesmus karawajewi Lohmander, 1928} Fig. 2, Map 2.

MATERIAL. 4 우, 15 juv., Stavropol Territory, Stavropol City, Mamaysky Forest, 2.VIII.2012; $8 \sigma^{\top} \sigma^{7}, 22$ 우, same locality, 27.X.2012; 2 ठ $\sigma^{7}, 6$ 우, 2 juv., same locality, 29.VI.2013; 1 juv., same locality, 3.VIII.2013; $6 \sigma^{\top} \sigma^{\top}, 2$ 우, same locality, 28.IX.2013; $1 \sigma^{\top}, 1$ ㅇ, same locality, 16.III.2014; 1 ○', Tamansky Forest, 12.IX.2013; 4 juv., Russky Forest, 27.VII.2013; 1 ऊ', 2 우, same locality, 12.X.2013; $1 \sigma^{7}, 8$ O+ , same locality, 10.VIII.2014; 12 $\sigma^{\top} \sigma^{\top}, 1$ 오, same locality, 23.VIII.2014; 3 우, 10 juv., Shpakovsky Distr., $5 \mathrm{~km}$ SSE of Izveshchatelnyi, Strizhament Mountain, forest, 14.VII.2013; 2 juv., Georgievsky Distr., Georgievsk, Safonovsky Forest, 10.VIII.2013; 1 ○', 16 우, Predgornyi Distr., Pyatigorsk, Beshtau Mountain, forest, 21.VII.2013, all leg. R.V. Zuev.

REMARKS. A Caucasian species known from the Karachayevo-Cherkessian and Kabardino-Balkarian republics of Russia, as well as in Georgia and Armenia [Lohmander, 1928, 1936; Kobakhidze, 1965]. We collected it in woods in different parts of the region, where it seems to be the most common member of the family Polydesmidae. These seem to be the northernmost records of this species. A habitus picture is given for an easier identification (Fig. 2). 
Brachydesmus assimilis Lohmander, 1936

Fig. 3, Map 2.

MATERIAL. $1 \sigma^{7}$, Stavropol Territory, Kochubeevsky Distr., Nevinnomyssk, confluence of Bolshoy Zelenchuk and Kuban rivers, floodplain forest, 7.IX.2014, leg. R.V. Zuev.

REMARKS. This is the first formal record of $B$. assimilis in Russia, extending its distribution far to the north. Originally described from eastern Georgia [Lohmander, 1936], it has now been found in a floodplain forest of Kuban River. Apparently, B. assimilis penetrates into the Stavropol Territory from the mountain regions of the Caucasus during floods.

A gonopod is illustrated to document the identification (Fig. 3).

\section{Brachydesmus superus Latzel, 1884}

MATERIAL. $1 \sigma^{\top}$, Stavropol Territory, Stavropol City, Tamansky Forest, 5.II.2013; $8 \sigma^{7} \sigma^{7}$, same locality, 9.X.2013; $2 \sigma^{7} \sigma^{7}, 1$, same locality, 18.I.2014; 2 O' $\sigma^{7}$, same locality, 18.II.2014; 1 O', same locality, 8.IV.2014, all leg. R.V. Zuev.

REMARKS. This ubiquitous anthropochore species is common throughout Europe, including the Ukraine and central Russia [Blower, 1985; Lokshina, 1969; Chornyi, Golovatch, 1993]; recently recorded in Asian Russia as well [Nefediev et al., 2014]. In the Stavropol Territory, it is likewise an introduction found

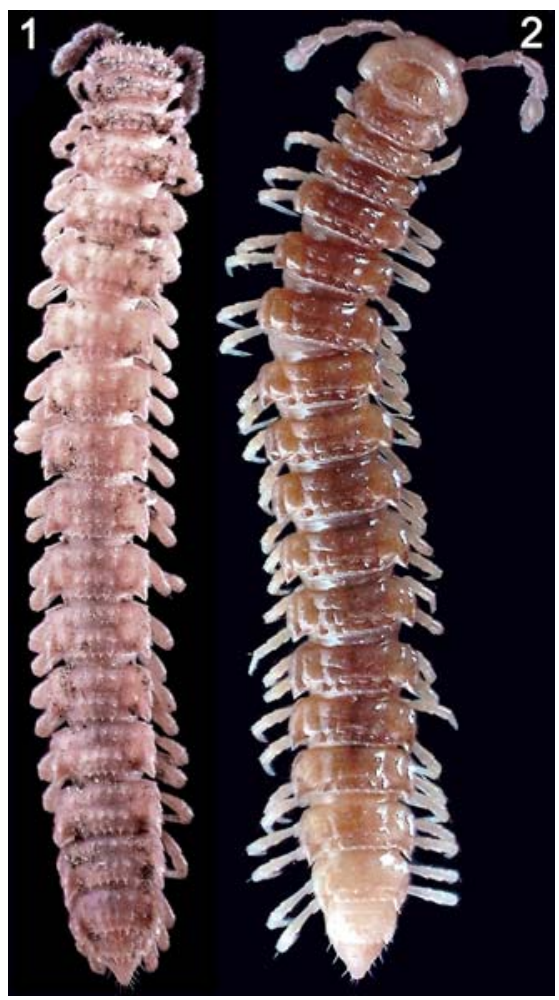

Figs 1 \& 2. Habitus pictures of Polydesmus muralewiczi Lohmander, $1936\left(\mathrm{O}^{7}\right)$ and Brachydesmus karawajewi Lohmander, $1928(+)$, respectively, dorsal views, taken not to scale.

Рис. 1, 2. Фотографии общего вида соответственно Polydesmus muralewiczi Lohmander, $1936\left(\sigma^{7}\right)$ и Brachydesmus karawajewi Lohmander, 1928 (), сверху, без масштаба.

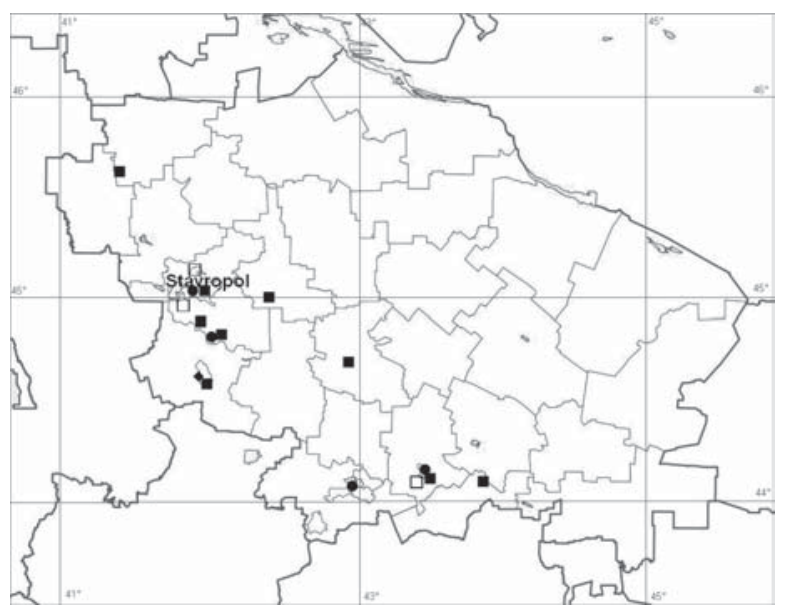

Map 2. Distribution of millipedes in the Stavropol Territory: circle - Brachydesmus karawajewi; square - Nopoiulus kochii; diamond - Brachydesmus assimilis, open square - Unciger transsilvanicus.

Карта 2. Распространение двупарноногих многоножек в Ставропольском крае: круг — Brachydesmus karawajewi; квадрат — Nopoiulus kochii; ромб — Brachydesmus assimilis; незакрашенный квадрат — Unciger transsilvanicus.

only in the vicinity of a human settlement. This is the first formal record of B. superus in the Caucasus. Interestingly, some individuals were found surface-active in January and February during thaws, although the soil temperature was close to $0^{\circ} \mathrm{C}$.

\section{ORDER JULIDA}

Family BLANIULIDAE

\section{Archiboreoiulus pallidus (Brade-Birks, 1920)}

MATERIAL. 1 , Stavropol Territory, Stavropol City, Tamansky Forest, 12.IX.2013; 7 우, same locality, 17.IV.2014, all leg. R.V. Zuev.

REMARKS. In Eastern Europe, this pan-European species is represented mainly by synanthropic parthenogenetic populations [Blower, 1985; Chornyi, Golovatch, 1993].

\section{Nopoiulus kochii (Gervais, 1847) Map 2.}

MATERIAL. 1 juv., Stavropol Territory, Stavropol City, Tamansky Forest, 14.V.2011; 2 juv., same locality, 14.IV.2012; 1 , same locality, 28.IV.2013; $1 \sigma^{7}$, same locality, 8.IV.2014; $1 \sigma^{7}, 1$ ㅇ, same locality, 17.IV.2014; 2 오, same locality, 19.IV.2014; $2 \sigma^{7} \sigma^{7}$, 1 , Russky Forest, 9.III.2014; 1 , same locality, 16.III.2014; 1 , Tatarsky Forest, 3.V.2013; $3 \sigma^{\top} \sigma^{\top}$, Elagin Pond, shore, under stone, 28.IX.2013; 2 우오, Botanical Garden, 20.IX.2011; 1 ऽ, 2 오오, same locality, 10.X.2012; 7 우, Shpakovsky Distr., 5 km SSE of Izveshchatelnyi, Strizhament Mountain, forest, 14.VII.2013; $6 \sigma^{\top} \sigma^{\top}, 4$ ㅇ, near Rynok, Nedremannaya Mountain, forest, 19.IV.2013; 1 , same locality, 15.VII.2014; 2 우, Krasnogvardeysky Distr., Ladovskaya Balka, pond bank, under stone, 15.IX.2013; 1 \%, Grachevsky Distr., $1 \mathrm{~km} \mathrm{SW}$ of Beshpagir, forest, 17.VII.2014; 5 $\sigma^{\top} \sigma^{\top}, 10$ 우, Kochubeevsky Distr., Nevinnomyssk, confluence of Bolshoy Zelenchuk and Kuban rivers, floodplain forest, 7.IX.2014; 1 ㅇ, Alexandrovsky Distr., Kruglolesskoe, 26.IV.2014; 2 juv., Kirovsky Distr., near Kommayak, forest belt, soil, 10.VII.2013; 1 


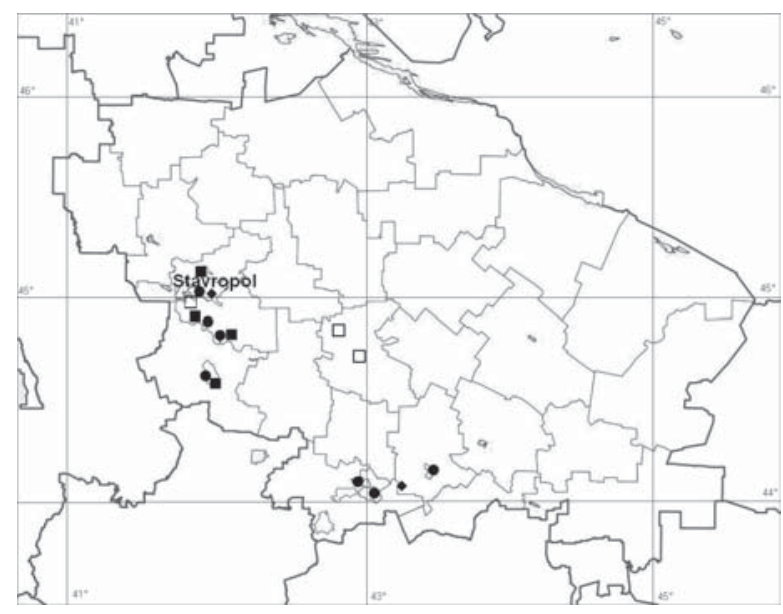

Map 3. Distribution of millipedes in the Stavropol Territory: circle - Nemasoma caucasicum; square - Cylindroiulus pterophylacum; diamond - Chaetoleptophyllum flexum; open square Julus colchicus.

Карта 3. Распространение двупарноногих многоножек в Ставропольском крае: круг — Nemasoma caucasicum; квадрат - Cylindroiulus pterophylacum; ромб - Chaetoleptophyllum flexum; незакрашенный квадрат - Julus colchicus.

q, Georgievsky Distr., Georgievsk, Safonovsky Forest, 10.VIII.2013, all leg. R.V. Zuev; 2 juv., same locality, 10.VIII.2014, leg. L.P. Ermolina.

REMARKS. In the Stavropol Territory, this ubiquitous species, possibly of Caucasian origin, has been recorded at Georgievsk and Novopavlovskaya [Golovatch, Enghoff, 1990].

\section{Family NEMASOMATIDAE}

Nemasoma caucasicum (Lohmander, 1932) Map 3.

MATERIAL. $4 \sigma^{\top} \sigma^{\top}, 2$, 9 , 1 juv., Stavropol Territory, Stavropol City, Tamansky Forest, 14.V.2011; 5 90, same locality, 14.IV.2012; 1 O, 2 juv., same locality, 13.X.2012; 3 o+ , same locality, 3.V.2013; $1 \Im^{2}, 3$ 우, same locality, 15.VI.2013; 1 ア, 3 우, same locality, 12.IX.2013; $1 \sigma^{\top}$, same locality, 13.IV.2014; 1 ㅇ, Mamaysky Fo-

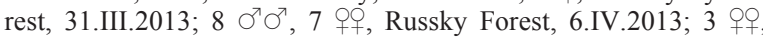
same locality, 27.VII.2013; $1 \sigma^{\top}, 1$ ․, 2 juv., same locality, 2.III.2014; $2 \sigma^{\top} \sigma^{\top}, 6$ OO, same locality, in the tinder, 3.XI.2013; $4 \sigma^{\top} \sigma^{\top}, 3$ 우, Shpakovsky Distr., 5 km SSE of Izveschatelnyi, Strizhament Mountain, forest, 14.VII.2013; $1 \sigma^{7}, 2$ oᄋ, near Rynok, Nedremannaya Mountain, forest, 19.IV.2013; $1 \sigma^{7}$, Kochubeevsky Distr., Nevinnomyssk, confluence of Bolshoy Zelenchuk and Kuban rivers, floodplain forest, 7.IX.2014; 2 90, Predgornyi Distr., Pyatigorsk, Mashuk Mountain, forest, 20.VII.2013; 1 శ, 2 juv., Beshtau Mountain, forest, 21.VII.2013; 2 ○ $\sigma^{7}, 10$ 우, 1 juv., Georgievsky Distr., Georgievsk, Safonovsky Forest, 10.VIII.2013, all leg. R.V. Zuev.

REMARKS. This Caucaso-Anatolian species is known from Georgia, Armenia, Azerbaijan and the Republic of Daghestan, Russia [Lohmander, 1932, 1936; Enghoff, 1985]. It has also been recorded in the Stavropol Territory, at Kislovodsk, as inhabiting Turdus merula and T. iliacus nests [Golovatch, Matyukhin, 2011]. This species is common in the region, occurring under the bark, often together with Nopoiulus kochii.

\section{Family JULIDAE}

Julus colchicus Lohmander, 1936 Fig. 4, Map 3

MATERIAL. $1 \sigma^{\nearrow}, 1$, Stavropol Territory, Alexandrovsky Distr., near Severnoe, forest belt, 26.IV.2014; 1 juv., $7 \mathrm{~km} \mathrm{NW}$ of Alexandrovskoe, forest belt, 26.IV.2014; 1 o', 1 , Shpakovsky Distr., near Grushevyi, steppe, under rock, 4.X.2014, all leg. R.V. Zuev.

REMARKS. This seems to be the easternmost record of $J$. colchicus. Described from Abkhazia and Ajaria, Georgia [Lohmander, 1936], later found in Turkey [Enghoff, 2006], it has also been listed in the Republic of Adygea (near Maikop) and along the Black Sea coast of Krasnodar Territory [Lang, 1959; Kobakhidze, 1965; Chumachenko, 2013].

A picture is provided of the body, especially its long and slender epiproct, and coloration of this species (Fig. 5).

\section{Chaetoleptophyllum flexum Golovatch, 1979} Fig. 5, Map 3.

MATERIAL. 2 우, Stavropol Territory, Stavropol City, Tatarsky Forest, nest of Turdus merula, 11.VI.2010, leg. B.K. Kotti; 1 $\sigma^{7}$, Botanical Garden, 16.VI.2012; 1 ㅇ, same locality, 26.III.2014; 1 O, same locality, 10.IV.2014; 1 ऽ, 1 \%, Mamaysky Forest, 28.IX.2013; 3 OO, 1 juv., Tamansky Forest, 10.IX.2013; 1 juv., same locality, 12.IX.2013; 1 , same locality, 4.X.2013; 2 우, same locality, 9.X.2013; 1 ऽ, 2 우, same locality, 17.IV.2014; 1 ㅇ, same locality, 1.VI.2014; 1 juv., Georgievsky Distr., Lysogorskaya, Lysaya Mountain, forest belt, 19.VII.2013, all leg. R.V. Zuev.

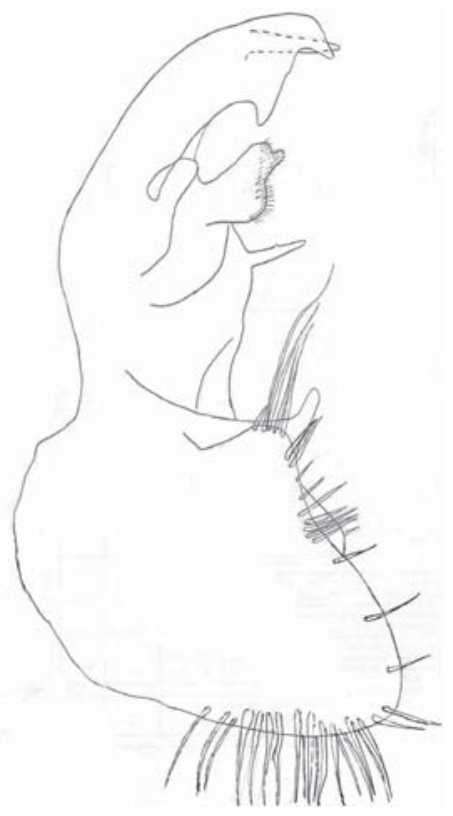

Fig. 3. Left gonopod of Brachydesmus assimilis Lohmander, 1936, mesal view, drawn not to scale.

Рис. 3. Левый гонопод Brachydesmus assimilis Lohmander, 1936, изнутри, нарисовано без масштаба. 
REMARKS. This seems to be the northernmost record of $C$. flexum. This species has hitherto been reported from Georgia and the mountainous regions of the Republic of Adygea, Russia [Golovatch, 1979; Chumachenko, 2013]. Interestingly, 2 specimens of $C$. flex$u m$ have been found in a Turdus merula nest, suggesting occasional ornithochory. A picture is provided to show the characteristically slender body and coloration of this species (Fig. 5).

\section{Cylindroiulus pterophylacum Read, 1992 Fig. 6, Map 3.}

MATERIAL. $2 O^{\top} \sigma^{7}, 3$ 우, Stavropol Territory, Stavropol City, Tamansky Forest, 15.IV.2011; 1 \&, same locality, 16.VII.2010;

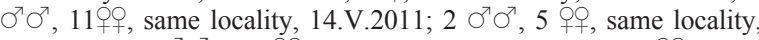
7.IV.2012; $9 \sigma^{7} \sigma^{7}, 17$ OPO , same locality, 8.IX.2012; 2 우, same locality, 13.X.2012; $4 \sigma^{\top} \sigma^{\top}, 21$ 우, same locality, 28.IV.2013; 2 $\sigma^{7} \sigma^{7}, 7$ 우, same locality, 10.IX.2013; $1 \sigma^{7}, 3$ OP , same locality, 12.IX.2013; $3 \sigma^{7} \sigma^{7}, 2$ 우, same locality, 5.X.2013; 1 , same locality, 8.IV.2014; $4 \sigma^{\top} \sigma^{7}, 7$ 우, Mamaysky Forest, 28.IX.2013; 2 O $^{\top} \sigma^{\top}, 5$ 우, 1 juv., Tatarsky Forest, 3.V.2013; $2 \bigcirc^{\top} \odot^{7}, 5$ 우, Russky Forest, 6.IV.2013; 2 O $^{7}, 5$ 오, same locality, 6.VII. 2013; 2 O$^{7} \sigma^{7}, 14$ 오, 4 juv., same locality, 27.VII.2013; 1 +, same locality, 16.III. 2014; 14 우, same locality, 23.VIII.2014; $1 \bigcirc^{7}, 12$ 우, 5 juv., Shpakovsky Distr., $5 \mathrm{~km}$ SSE of Izveshchatelnyi, Strizhament Mountain, forest, 14.VII.2013; 6 O $^{7} \bigcirc^{7}, 10$ 우, 5 juv., near Rynok, Nedremannaya Mountain, forest, 19.IV.2013; $2 \sigma^{\top} \sigma^{7}, 2$ 오. Kochubeevsky District, Nevinnomyssk, confluence of Bolshoy Zelenchuk and Kuban rivers, floodplain forest, 7.IX.2014, all leg. R.V. Zuev.

REMARKS. A Caucasian species known only from Georgia, as well as the Karachayevo-Cherkessian Republic, the Republic of Adygea and the Krasnodar Territory of Russia [Read, 1992]. A picture is provided to show the characteristically bulky body and purplish coloration of this small species (Fig. 6).

\section{Cylindroiulus arborum Verhoeff, 1928}

Figs 7-9.

MATERIAL. $1 \sigma^{7}, 1$, Stavropol Territory, Stavropol City, Russky Forest, 9.III.2014; 1 †, Tamansky Forest, 15.IV.2011, all leg. R.V. Zuev.

REMARKS. This seems to be the first formal record of $C$. arborum in Russia proper, also being the easternmost one. This species is known from Central and Eastern Europe, as well as in the Balkans. Within the former Soviet Union, it was reported from Lithuania and Ukraine (Transcarpathian Region and Kiev) [Schubart, 1934; Lang, 1954].

Several illustrations are provided to document the identification (Figs 7-9).

Unciger transsilvanicus (Verhoeff, 1899)

Figs 10 \& 11, Map 2.

MATERIAL. 1 , Stavropol Territory, Shpakovsky Distr., near Grushevyi, steppe, under a log, 20.IV.2011; 1 ₹ , 2 of, same locality, under stones, 28.X.2013; 2 क+ , Stavropol City, Tatarsky Forest, meadow, under log, 16.X.2012; 1 juv., Russky Forest, 10.V.2014; $1 \sigma^{\top}$, same locality, 7.VI.2014; 1 क, Georgievsky Distr., Georgievsk, Safonovsky Forest, 10.VIII.2013, all leg. R.V. Zuev.

REMARKS. This Eastern European species ranges up to the Rostov-on-Don Region in the southeast [Golovatch, 1992]. Moreover, U. transsilvanicus has recent-

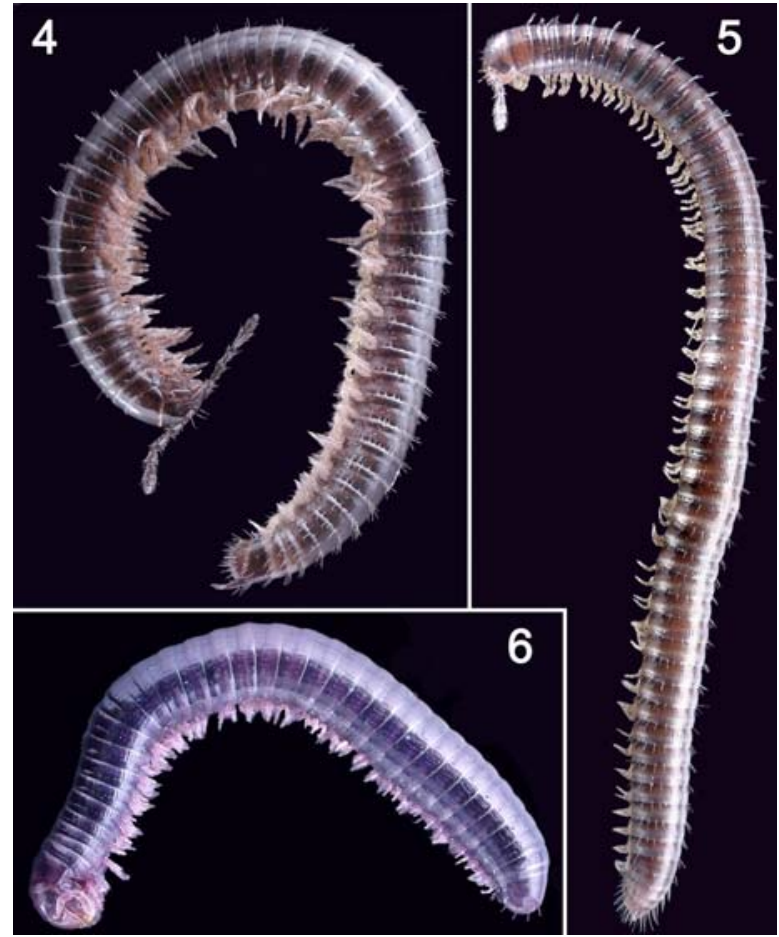

Figs 4-6. Habitus pictures of Julus colchicus Lohmander, $1936\left(\sigma^{7}\right)$, Chaetoleptophyllum flexum Golovatch, 1979 (†) and Cylindroiulus pterophylacum Read, 1992 (+), respectively, lateral views, taken not to scale.

Рис. 4-6. Фотографии общего вида соответственно Julus colchicus Lohmander, 1936 ( $\left.\sigma^{7}\right)$, Chaetoleptophyllum flexum Golovatch, 1979 (†) и Cylindroiulus pterophylacum Read, 1992 $(+)$, сбоку, без масштаба.

ly been recorded from near Georgievsk, Stavropol Territory [Evsyukov, Golovatch, 2013].

Lohmander [1936], when describing U. kubanus Lohmander, 1936 as based on five specimens coming from near Armavir and Psebai, pointed out its great similarity in structure of the gonopods to U. transsilvanicus. The main differences between the two species lie in the constriction between the pro- and metazonites being less pronounced and the tergal setae somewhat shorter in $U$. kubanus as compared to $U$. transsilvanicus [Lohmander, 1936]. The new material fully fits the description of $U$. kubanus, but, given the great similarity of the two formal congeners and the small material available as yet, the above variations may well prove to be individual or populational. Lohmander [1936] also admitted that. Any discussion of the status of $U$. kubanus is thus to be deferred until more material becomes accumulated for comparative analyses, preferably coming from many places and employing molecular techniques as well.

New illustrations are provided to document the identification, including the characteristic uncus on the hypoproct (Figs $10 \& 11$ ).

\section{Brachyiulus jawlowskii Lohmander, 1928}

MATERIAL. 16 juv., Stavropol Territory, Stavropol City, farm, 4.IX.2011, leg. L.N. Kharchenko. 

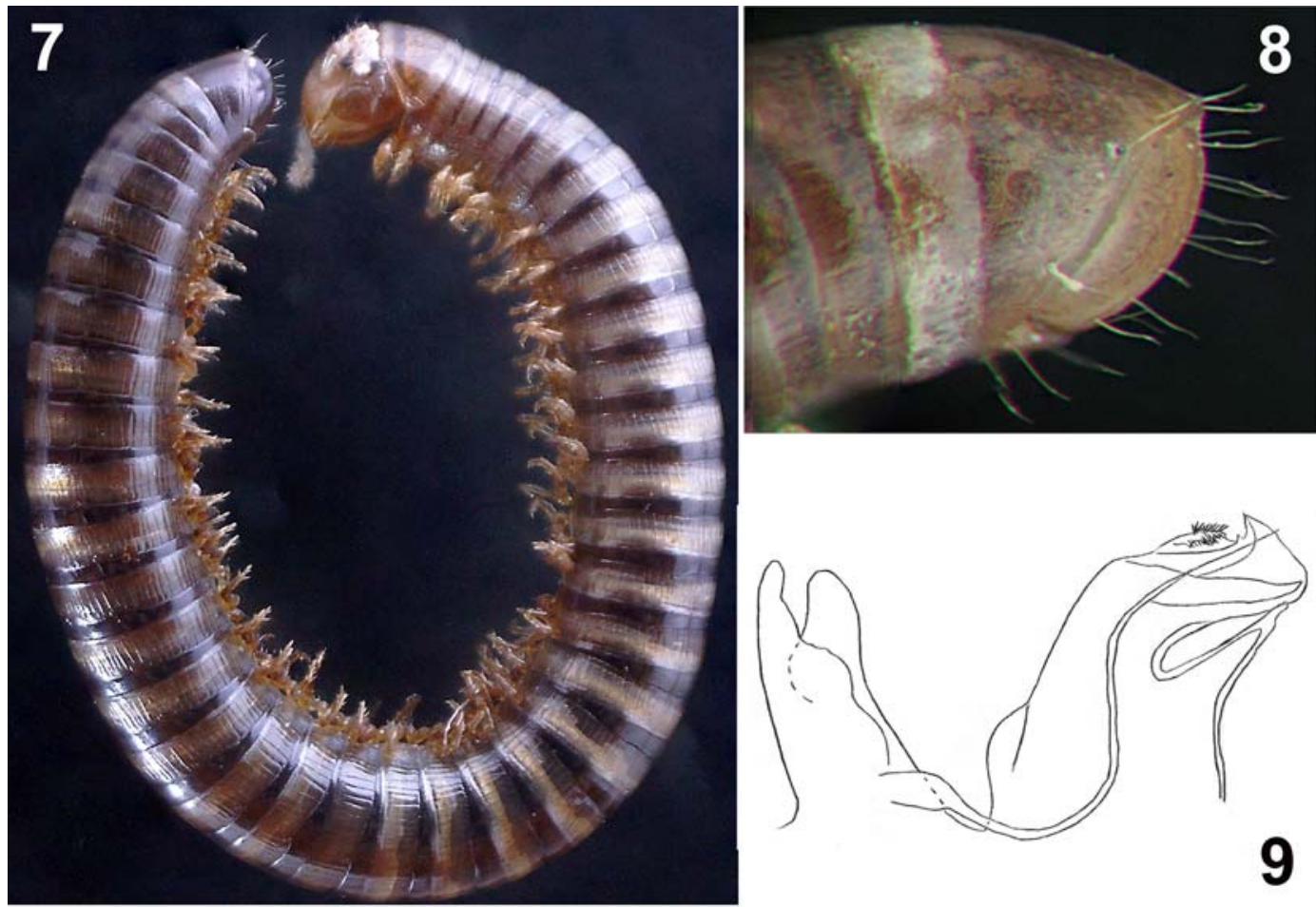

Figs 7-9. Cylindroiulus arborum Verhoeff, 1928, $\odot$, habitus, telson and left gonopods, lateral, lateral and mesal views, respectively, not to scale.

Pис. 7-9. Cylindroiulus arborum Verhoeff, 1928, , общий вид, тельсон и левые гоноподы, соответственно сбоку, сбоку и изнутри, без масштаба.

REMARKS. Subendemic to the Russian Plain, this species is known from Romania, Poland, Ukraine and European Russia, down to the Rostov-on-Don Region in the south [e.g. Lokshina, 1969; Golovatch, 1984; Evsyukov, Golovatch, 2013]; recently recorded also in Asian Russia and western Kazakhstan [Nefediev et al., 2014]. Within the Stavropol Territory, B. jawlowskii has not been found in natural habitats, likely being purely synanthropic.

\section{Megaphyllum brachyurum (Attems, 1899) Map 4.}

MATERIAL. $2 \sigma^{7} \sigma^{7}$, Stavropol Territory, Stavropol City, Tamansky Forest, 17.VII.2011; $1 \sigma^{7}$, same locality, 14.IV.2012; 2 juv., same locality, 5.X.2013; $1 \mathrm{O}^{7}, 1$ juv., same locality, 8.IV.2014; 1 juv., Russky Forest, 12.X.2013; $3 \bigcirc^{7} \sigma^{7}, 4$, $+9,2$ juv., same locality, 7.VI.2014; 1 , same locality, 10.VIII.2014; 2 우, Shpakovsky Distr., $5 \mathrm{~km}$ SSE of Izveschatelnyi, Strizhament Mountain, forest, 3.VI.2010;

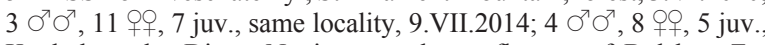
Kochubeevsky Distr., Nevinnomyssk, confluence of Bolshoy Zelenchuk and Kuban rivers, floodplain forest, 7.IX.2014; 2 juv., Andropovsky Distr., 3 km S of Novyi Yankul, 12.IV.2014; 2 우, 2 juv., Alexandrovsky Distr., near Kruglolesskoe, forest belt, 26.IV. 2014; 2 우, 1 juv., Georgievsky Distr., Georgievsk, Safonovsky Forest, 10.VIII.2013; 2 क्+, 8 juv., Lysogorskaya, Lysaya Mountain, forest belt, 19.VII.2013, all leg. R.V. Zuev.

REMARKS. The species is known from Azerbaijan, Georgia, as well as Turkey, northwestern Iran and the Republic of Daghestan, Russia [Lohmander, 1936; Enghoff, Moravvej, 2005; Enghoff, 2006]. In addition, it has recently been found in the Stavropol Territory
(Kislovodsk) and in the Republic of Kalmykia in nests of Turdus merula [Golovatch, Matyukhin, 2011]. It occurs in forests throughout the region.

\section{Megaphyllum rossicum (Timotheew, 1897) Map 4.}

MATERIAL. $2 \bigcirc^{7} \sigma^{\top}, 9$ 우, 1 juv., Stavropol Territory, Stavropol City, Tamansky Forest, 28.IV.2013; $2 \sigma^{7} \sigma^{7}, 1$ ㅇ, Russky Forest, 12.X.2013; $1 \sigma^{7}$, same locality, 9.III.2014; $5 \sigma^{7} \sigma^{7}, 7$ + 0 , 2 juv., same locality, 7.VI.2014; 1, 1 juv., Tatarsky Forest, 16.X.2012; 2 $\sigma^{7} \sigma^{7}, 4$, + , 1 juv., same locality, 3.V.2013; 1 , Botanical Garden, 20.IX.2011; $4 \sigma^{7} \sigma^{\top}, 5$ 우, Shpakovsky Distr., near Grushevyi, steppe, 20.IV.2011; 2 OT $^{7}, 5$ 우, same locality, 2.V.2011; $1 \sigma^{7}, 1$ +, same locality, 11.V.2013; 1 O', 2 ㅇ, same locality, 27.III.2014; 1 , near Tsimlyansky, steppe, 16.V.2011; $1 \bigcirc^{\top}, 1 \%$, same locality, 27.V.2011; $2 \bigcirc^{7} \sigma^{\top}, 3$, $9,5 \mathrm{~km}$ SSE of Izveshchatelnyi, Strizhament Mountain, forest, 3.VI.2010; $2 \sigma^{7} \sigma^{7}$, same locality, 9.VII.2014; $4 \sigma^{7} \sigma^{7}, 2$ 오, same locality, 11.VII.2014; $2 \sigma^{7} \sigma^{7}, 2$ 오, near Sadovyi, forest belt, 26.IV.2014; $3 O^{7} O^{\top}, 1$, 1 juv., Grachevsky Distr., Beshpagir, pine plantations, 15.V.2011; $3 \mathrm{O}^{\top} \sigma^{\top}, 15$ 우, 5 juv., same locality, 8.VII.2014; 2 O $^{7} \sigma^{\top}, 2$ 우, 1 km SW of Beshpagir, forest, 17.VII.2014; 2 of , near Tuguluk, steppe, 21.V.2013; 1 +, 6 juv., near Basovyi, forest belt, 26.IV.2014; $20^{7} \sigma^{7}$, Kochubeevsky Distr, Nevinnomyssk, confluence of Bolshoy Zelenchuk and Kuban rivers, floodplain forest, 7.IX.2014; $10^{7}$, Andropovsky Distr., Ovrazhnyi, 12.IV.2014; 5 우, 21 juv., Alexandrovsky Distr., Severnoe, forest belt, 26.IV.2014; $3 \mathrm{O}^{7} \mathrm{O}^{7}, 2$ 우, 2 juv., Kruglolesskoe, forest belt, 26.IV.2014; $1 \sigma^{7}$, Predgornyi Distr., near Kislovodsk, Borgustansky Ridge, steppe, 20.VII.2013; 1 , Pyatigorsk, Beshtau Mountain, forest 21.VII.2013; 1 + 1 juv., Novoselitsky Distr., near Zhuravskoye, forest belt, 20.VI.2013; 2 oᄋ 10 juv., Blagodarnensky Distr., near Elizavetinskoe, forest belt, 19.VI.2013, all leg. R.V. Zuev; $10^{2}, 7$ 우, Georgievsky Distr., 

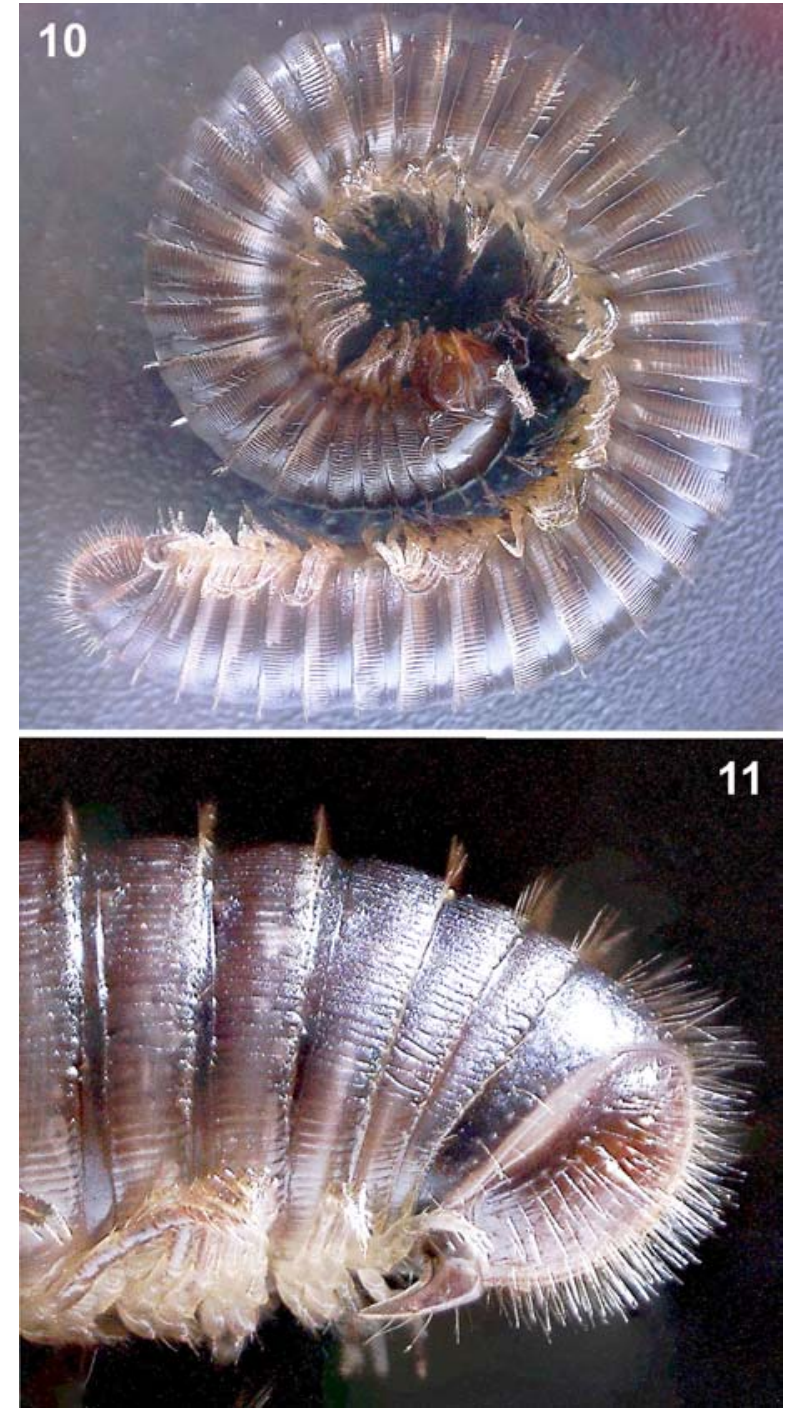

Figs 10 \& 11. Unciger transsilvanicus (Verhoeff, 1899),, , habitus and posterior body end, respectively, lateral view, not to scale.

Рис. 10, 11. Unciger transsilvanicus (Verhoeff, 1899), 우, соответственно общий вид и задняя часть тела, сбоку, без масштаба.

Georgievsk, field, 9.VI.2014, leg. L.P. Ermolina; $1 O^{\top 1}, 2$ 우, Apanasenkovsky Distr., Belye Kopani, 2.VI.2004, leg. B.K. Kotti.

REMARKS. Subendemic to the Caucasus and the southern half of the Russian Plain, M. rossicum is also known from Bulgaria and Greece [Golovatch, 1984]. Originally this species was described in part from material coming from Kislovodsk, Stavropol Territory [Timotheew, 1897], whence it has also been found in bird nests [Golovatch, Matyukhin, 2011]. A common species in the Stavropol Territory, occurring nearly in all habitats, with the exception of dry steppes and semideserts covering the eastern parts of the region.

Rossiulus kessleri (Lohmander, 1927) Map 4.

MATERIAL. $1 \sigma^{7}$, Stavropol Territory, Stavropol City, 19.V.2010; $1 \sigma^{7}, 3$ 우, Russky Forest, 7.VI.2014; 1 , Shpakovsky

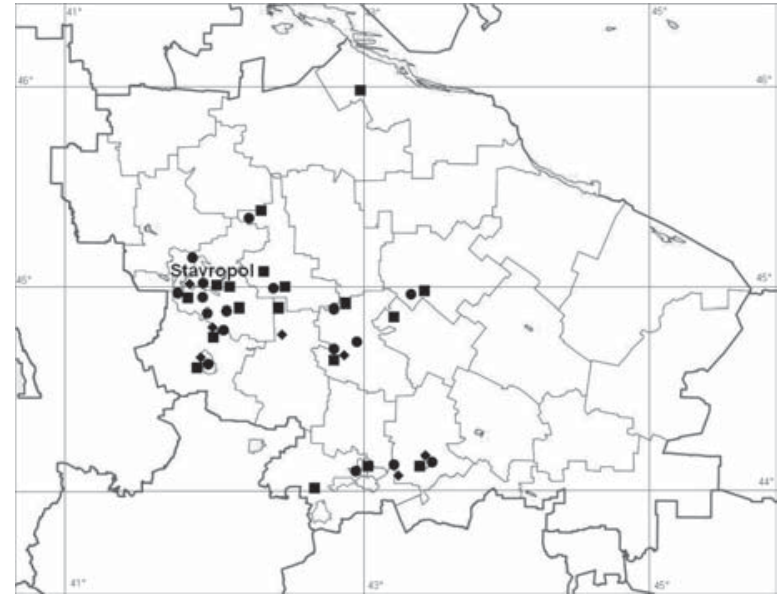

Map 4. Distribution of millipedes in the Stavropol Territory: circle - Rossiulus kessleri; square - Megaphyllum rossicum; diamond - Megaphyllum brachyurum.

Карта 4. Распространение двупарноногих многоножек в Ставропольском крае: круг - Rossiulus kessleri; квадрат Megaphyllum rossicum; ромб - Megaphyllum brachyurum.

Distr., near Grushevyi, steppe, 27.III.2014; 3 우, 6 juv., near Tsimlyansky, steppe, 16.V.2011; 10 우, same locality, 27.V.2011; 7 $\sigma^{7} \sigma^{7}, 7$ 우, same locality, 20.V.2013; $5 \sigma^{7} \sigma^{7}, 5$ 우, near Novomarevskaya, steppe, in manure, 6.VI.2011; $3 \sigma^{7} \sigma^{7}, 3$ 우, near Tatarka, steppe, 27.V.2013; $1 \sigma^{7}, 3$ 우, $5 \mathrm{~km}$ SSE of Izveshchatelnyi, Strizhament Mountain, forest, 3.VI.2010; $3 \sigma^{7} \sigma^{7}, 3$ 오, 2 juv., same locality, 9.VII.2014; 5 O $^{7} \sigma^{7}, 3$ 우, same locality, 11.VII.2014; $1 \mathrm{O}^{\top}, 3$ 우, near Rynok, Nedremannaya Mountain, steppe, 15.VII.2014; 1 O$^{7}, 3$ 우, Grachevsky Distr., near Tuguluk, steppe, 21.V.2013; 4 우, same locality, 16.VII.2014; $10^{7}, 2$ 우, $1 \mathrm{~km} \mathrm{SW}$ of Beshpagir, forest, 17.VII.2014; 1 \%, 2 juv., Alexandrovsky Distr., near Severnoe, forest belt, 26.IV.2014; 2 우, 15 juv., near Kruglolesskoe, forest belt, 26.IV.2014; 2 +क, near Alexandrovskoe, steppe, 8.VI.2011; 3 우, 3 juv., Kochubeevsky District, Nevinnomyssk, confluence of Bolshoy Zelenchuk and Kuban rivers, floodplain forest, 7.IX.2014; $6 \sigma^{7} \sigma^{7}, 3$ 우, 2 juv., Predgornyi Distr., near Pyatigorsk, Beshtau Mountain, forest 21.VII.2013; 3 q9, same place, steppe, 21.VII.2013; 1 + , Georgievsky Distr., Georgievsk, Safonovsky Forest, 10.VIII.2013; 1 , near Lysogorskaya, Lysaya Mountain, forest belt, 19.VII.2013; 1 juv., Blagodarnensky Distr., near Elizavetinskoe, forest belt, 19.VI.2013, all leg. R.V. Zuev.

REMARKS. Endemic to the Russian Plain, ranging from the central regions of Belarus to the Urals in the east and from the Arkhangelsk Region in the north to the Caucasus Major in the south [Golovatch, 1984]. In the Stavropol Territory, it has been recorded at Pyatigorsk [Lohmander, 1936] and Kislovodsk (in a Troglodytes troglodytes nest) [Golovatch, Matyukhin, 2011], being about as common in the region as Megaphyllum rossicum. However, $R$. kessleri seems to be less common in the woods, being more resistant to drought. In the steppe habitats, $R$. kessleri often aggregates after rains on limestone outcrops and at fresh manure.

\section{Conclusions}

As a result of our studies, the millipede fauna of the Stavropol Territory is found to include at least 19 species, 12 of which are recorded in the region for the first time, including two new to the fauna of Russia: 
Brachydesmus assimilis Lohmander, 1936 and Cylindroiulus arborum Verhoeff, 1928. Four species seem to show their northernmost range limits in the Stavropol Territory: Polydesmus muralewiczi Lohmander, 1936, Brachydesmus assimilis Lohmander, 1936, Brachydesmus karawajewi Lohmander, 1928 and Chaetoleptophyllum flexum Golovatch, 1979. The known ranges of Julus colchicus Lohmander, 1936 and Cylindroiulus arborum Verhoeff, 1928 are extended far to the east. Future faunistic studies on the Diplopoda of Ciscaucasia and adjacent areas will undoubtedly reveal many further interesting discoveries.

The fauna is basically Caucasian, but the share of widespread, often anthropogenic species is also very considerable. A more detailed zoogeographical analysis, however, is premature.

ACKNOWLEDGEMENTS. I thank all colleagues who provided additional material for the present study. I am deeply indebted to S.I. Golovatch (Moscow, Russia) for providing the relevant literature and assisting both in the identification and publication of material.

\section{References}

Blower J.G. 1985. Millipedes. Keys and notes for the identification of the species // Synopses of the British Fauna. No.35. 242 pp.

Chornyi N.G., Golovatch S.I. 1993. [Millipedes (Diplopoda) of the plain territories of the Ukraine]. Kiev. 54 pp. [in Russian, English abstract].

Chumachenko Yu.A. 2013. [Features of the altitudinal distribution of soil mesofauna in the northwestern Caucasus] // Trudy Kavkazskogo gosudarstvennogo prirodnogo biosfernogo zapovednika. T.20. P.44-60 [in Russian].

Enghoff H. 1985. The milliped family Nemasomatidae. With description of a new genus, and a revision of Orinisobates (Diplopoda: Julida) // Entomologica scandinavica. Vol.15. P.27-67.

Enghoff H. 2006. The millipedes of Turkey (Diplopoda) // Steenstrupia. Vol.29. No.2. P.175-198.

Enghoff H., Moravvej S.A. 2005. A review of the millipede fauna of Iran (Diplopoda) // Zoology in the Middle East. Vol.35. P.61-72.

Evsyukov A.P., Golovatch S.I. 2013. Millipedes (Diplopoda) from the Rostov-on-Don Region, southern Russia // Arthropoda Selecta. Vol.22. No.3. P.207-215.

Evsyukov A.P., Golovatch S.I., Reip H. 2015. The millipede genus Strongylosoma Brandt, 1833 in the Caucasus (Diplopoda, Polydesmida, Paradoxosomatidae) // Acta Societatis Zoologica Bohemiae (in press).

Golovatch S.I. 1979. [Three genera of Diplopoda - Chilognatha new to the USSR fauna] // Zoologicheskii Zhurnal. T.58. No.3. P.336-343 [in Russian, English summary].

Golovatch S.I. 1984. [The distribution and faunogenesis of millipedes of the USSR European part] // Chernov Yu.I. (ed.). Filogenez i filotsenogenez. Moscow: Nauka Publ. P.92-138 [in Russian].
Golovatch S.I. 1989. Diplopoda of the Caucasus, 3. Trachysphaeridae, with contributions to the fauna of Turkey // Senckenbergiana biologica. Bd.70. H.4-6. S.331-358.

Golovatch S.I. 1992. Some patterns in the distribution and origin of the millipede fauna of the Russian Plain // Ber. nat.-med. Vereins Innsbruck. Suppl.10. S.373-383.

Golovatch S.I. 2008. On three remarkable millipedes (Diplopoda) from the Crimea, Ukraine // International Journal of Myriapodology. Vol.1. P.97-110.

Golovatch S.I., Enghoff H. 1990. [The millipede Nopoiulus kochii (Gervais, 1847) in the Caucasus] // Striganova B.R. (ed.). Fauna nazemnykh bespozvonochnykh Kavkaza. Moscow: Nauka Publ. P.114-118 [in Russian].

Golovatch S.I., Matyukhin A.V. 2011. New records of millipedes (Diplopoda), mainly from bird nests, in European Russia // Arthropoda Selecta. Vol.20. No.2. P.115-116.

Kobakhidze D.N. 1965. [A list of the millipedes (Diplopoda) of SSR Georgia] // Fragmenta faunistica. T.11. No.21. P.389398 [in Russian].

Lang J. 1954. Mnohonožky - Diplopoda // Fauna ČSR Svazek 2. $187 \mathrm{pp}$.

Lang J. 1959. [Contribution to the knowledge of Diplopoda in the territory of the USSR] // Zoologicheskii Zhurnal. T.38. No.12. P.1790-1796 [in Russian, English summary].

Lignau N.G. 1907. [To the fauna of millipedes of the Caucasus] // Ezhegodnik Zoologicheskago muzeya Imperatorskoy akademii nauk. T.12. P.195-200 [in Russian].

Lokshina I.E. 1969. [Identification book of the millipedes (Diplopoda) in the plain parts of the USSR European territory]. Moscow: Nauka Publ. 78 pp. [in Russian].

Lohmander H. 1928. Neue Diplopoden aus Ukraine und dem Kaukasus. (2. Aufsatz über Diplopoden aus dem Sovjet-Gebiet) // Académie des Sciences de l'Ukraine. Mémoires de la Classe des Sciences Physiques et Mathématiques. T.6. Fasc.3. P.529-550.

Lohmander H. 1932. Neue transkaukasische Diplopoden. 4. Aufsatz über Diplopoden aus der Sowjet-Union // Zoologischer Anzeiger. Bd.98. H.7-8. S.171-182.

Lohmander H. 1936. Über die Diplopoden des Kaukasusgebietes // Göteborgs Kungliga Vetenskaps- och Vitterhets-Samhälles handlingar. Följden 5. Ser.B. Bd.5. H.1. 196 S.

Muralewicz W.S. 1907. Zur Myriapodenfauna des Kaukasus // Zoologischer Anzeiger. Bd.31. H.11-12. S.329-351.

Muralewicz W.S. 1927. [To the fauna of Myriapoda of the Caucasus] // Acta Societatis Entomologicae Stauropolitanae. T.3. No.1. P.4-7 [in Russian].

Nefediev P.S., Nefedieva J.S., Dyachkov Y.V. 2014. A review of the anthropochore millipede fauna of Asian Russia, with new records from the Altai Province, Siberia (Diplopoda) // Arthropoda Selecta. Vol.23. No.4. P.337-345.

Read H.J. 1992. The genus Cylindroiulus Verhoeff 1894 in the faunas of the Caucasus, Turkey and Iran (Myriapoda: Diplopoda: Julidae) // Senckenbergiana biologica. Bd.72. H.4-6. S. 373-433.

Schubart O. 1934. Tausendfüßler oder Myriapoda. I: Diplopoda. // Dahl F. (Hrsg.). Die Tierwelt Deutschlands. Teil 28. 318 S.

Timotheew T.E. 1897. [Two new species of Diplopoda] // Trudy obshchestva ispytateley prirody pri Kharkovskom Imperatorskom universitete. T.31. P.3-19 [in Russian].

Responsible editor S.I. Golovatch 